\title{
PENGARUH PERUBAHAN PETA HAZARD GEMPA INDONESIA TERHADAP PERENCANAAN PERKUATAN LERENG MENGGUNAKAN ANGKUR
}

\author{
Aprilia Tika Pratiwi ${ }^{1)}$, Dio Alif Hutama ${ }^{2)}$, Isnaniati ${ }^{3)}$, \\ 1) Progam Studi Teknik Sipil, Fakultas Teknik \\ Universitas Muhammadiyah Surabaya \\ Jl. Sutorejo No. 59 Surabaya, Telp 031-3811966 \\ Email: apriliatikapratiwi1769@gmail.com \\ 2) Progam Studi Teknik Sipil, Fakultas Teknik \\ Universitas Muhammadiyah Surabaya \\ Jl. Sutorejo No. 59 Surabaya, Telp 031-3811966 \\ Email: dioalifhutama@ft.um-surabaya.ac.id \\ ${ }^{3)}$ Progam Studi Teknik Sipil, Fakultas Teknik \\ Universitas Muhammadiyah Surabaya \\ Jl. Sutorejo No. 59 Surabaya, Telp 031-3811966 \\ Email: isnaniati65@gmail.com
}

\begin{abstract}
This paper discusses the comparison of changes in Indonesia's earthquake hazard map in 2010 and 2017, planning slope reinforcement using ground anchor with variations in reinforcement angle variations $(\theta)$, ratio of anchor length $(\mathrm{L} / \mathrm{H})$ and vertical distance (Sv) at anchor installation. Moreover, the Indonesian region is located in a very active tectonic zone so it is very vulnerable to earthquakes. In 2017 a revision was made of the Indonesian earthquake map where in the latest map there was a change in earthquake load plans for several regions, one of which was the Banyuwangi area. This research was conducted using a computer program that is Rocsience Slide 6.0 and manual calculation. The Rocsience Slide 6.0 program is used to calculate external stability (overell) while manual calculation is used to calculate internal stability and stability against failure of soil carrying capacity. The results of the analysis show the decreasing of safety factor (FS) for unreinforced slope due to changes in the 2010 to 2017 seismic load of 3,9\% calculated using Slide 6.0. Internal stability of pullout the decreasing of FS by $8,8 \%-10,2 \%$. Internal stability of rupture show the decreasing of FS by $8,5 \%-10,4 \%$. External stability against bearing capacity failure shows the decreasing of FS by $13,1 \%-13,8 \%$. Global stability show decreasing of FS by $4,2 \%-5,6 \%$.
\end{abstract}

Keywords : Ground Anchor, Slide 6.0, Seismic Hazard Maps, Slope

\begin{abstract}
Abstrak
Penelitian ini membahas mengenai perbandingan perubahan peta hazard gempa Indonesia tahun 2010 dan tahun 2017, merencanakan perkuatan lereng menggunakan angkur (ground anchor) dengan variasi variasi sudut perkuatan $(\theta)$, rasio panjang angkur $(\mathrm{L} / \mathrm{H}) \mathrm{dan}$ jarak vertikal (Sv) pada pemasangan angkur. Terlebih wilayah Indonesia terletak pada zona tektonik yang sangat aktif sehingga sangat rawan terhadap gempa bumi. Pada tahun 2017 dilakukan revisi terhadap peta gempa Indonesia dimana dalam peta terbaru tersebut terjadi perubahan beban gempa rencana untuk beberapa daerah salah satunya daerah Banyuwangi. Penelitian ini dilakukan dengan menggunakan program komputer yaitu Rocsience Slide 6.0 dan perhitungan manual. Program Rocsience Slide 6.0 digunakan untuk menghitung sta bilitas eksternal (overell) sedangkan perhitungan manual digunakan untuk menghitung stabilitas internal dan stabilitas terhadap kegagalan daya dukung tanah. Dari hasil penelitian perhitungan Slide 6.0 lereng tanpa perkuatan menunjukkan adanya penurunan besarnya FS dari perubahan beban gempa tahun 2010 ke 2017 sebesar 3,9\%. Stabilitas internal terhadap cabut tulangan menunjukkan adanya penurunan FS sebesar 8,8\% - 10,2\% dari beban gempa tahun 2010 ke 2017. stabilitas internal putus tulangan menunjukkan adanya perubahan FS sebesar $8,5 \%-10,4 \%$ dari beban gempa tahun 2010 ke 2017. Stabilitas eksternal terhadap kegagalan daya dukung menunjukkan adanya perubahan FS sebesar 13,1\% - 13,8\% dari beban gempa tahun 2010 ke 2017. Perhitungan Slide 6.0 stabilitas eksternal terhadap keruntuhan global menunjukkan adanya perubahan FS sebesar 4,2\% - 5,6\% dari beban gempa tahun 2010 ke 2017.
\end{abstract}

Kata Kunci: Ground Anchor, Slide 6.0, Peta Hazard Gempa, Lereng

\section{PENDAHULUAN}

Kemantapan (stabilitas) lereng merupakan suatu faktor yang sangat penting dalam pekerjaan yang berhubungan dengan penggalian, penimbunan tanah, batuan dan bahan galian, karena menyangkut persoalan keselamatan manusia (pekerja), keamanan peralatan serta kelancaran produksi. Stabilitas tanah pada lereng dapat terganggu akibat pengaruh alam, iklim dan aktivitas manusia. Dengan melakukan analisis, kita juga dapat menilai kemantapan lereng jangka pendek dan panjang, menilai kemungkinan kelongsoran yang melibatkan lereng alamiah dan lereng batuan, mengerti mekanisme kelongsoran dan pengaruh faktor lingkungan, sehingga memungkinkan rancangan ulang dari lereng yang telah runtuh, merencanakan dan merancang pengukuran perbaikan salah satu metode pencegahan bencana tanah longsor yaitu dengan memberikan perkuatan pada lereng, salah satu perkuatan lereng yang sering digunakan di dunia konstruksi adalah ground anchor. Ground anchors atau dalam bahasa disebut jangkar tanah yang berfungsi sebagai struktur perkuatan tanah, berupa baja yang disisipkan dalam formasi tanah dengan arah sudut kemiringan yang bervariasi (Artati,2001).

Pada umumnya faktor-faktor yang menyebabkan lereng tidak stabil adalah geometri lereng, kekuatan massa batuan lereng, struktur batuan, air tanah, beban luar dan tegangan insitu. Dari salah satu yang telah disebutkan di atas beban luar yang terjadi disebabkan karena adanya 
gempa bumi, terlebih wilayah indonesia terletak pada zona tektonik yang sangat aktif sehingga sangat rawan terhadap gempa bumi. Dalam mengantisipasi bahaya gempa, pemerintah Indonesia telah mempunyai standar peraturan perencanaan ketahanan gempa untuk stuktur bangunan gedung dan non gedung yaitu SNI-03-1726-2012 yang merupakan hasil revisi dari SNI-03-1726-2002. Perubahan mendasar dalam standar ini adalah ruang lingkup yang diatur dan diperluas, serta penggunaan peta-peta gempa yang baru dan format penulisan ditulis sesuai dengan Pedoman Standarisasi Nasional (PSN) 08:2007, selain itu terdapat pula standart SNI 8460-2017 tentang persyaratan perancangan geoteknik

Standar perencanaan umumnya selalu diperbarui guna mengakomodir perkembangan iptek dan data-data kejadian gempa terbaru. Dalam upaya merevisi peta gempa Indonesia ini dan untuk mengintegrasikan berbagai keilmuan terkait bidang kegempaan, maka pada tahun 2009 di bawah koordinasi Kementerian Pekerjaan Umum telah dibentuk Tim Revisi Peta Gempa Indonesia 2010, dan pada tahun 2016 para pakar dan peneliti gempa bumi menemukan sumber-sumber gempa bumi baru dengan potensi gempa yang cukup besar. Sumber-sumber gempa tersebut berupa sesar aktif atau patahan yang dihasilkan dari aksi gaya lempeng tektonik. Beberapa sesar ditemukan di pulau Jawa, seperti sesar Kendeng yang melintasi beberapa wilayah di Jawa Timur, yang mana sesar-sesar ini sebelumnya belum terdeteksi pada peta gempa tahun 2010. Oleh karena itu muncullah Revisi Peta Sumber dan Bahaya Gempa Indonesia tahun 2017. Peta ini merupakan hasil pemutakhiran peta gempa tahun 2010 (Litbang, 2016). Gempa rencana untuk lereng galian dan timbunan ditetapkan dengan kemungkinan terlewati besarannya selama umur rencana 50 tahun adalah $2 \%$ atau setara dengan periode ulang 500 tahun dengan mengacu pada peta gempa yang terdapat pada surat edaran Menteri Pekerjaan Umum No. 12/SE/M/2010. (RSNI3,2017), dapat kita liat dalam kedua peta tersebut mengalami suatu perubahan dalam besarnya pembebanan terutama daerah Jawa Timur tepatnya daerah Banyuwangi seperti yang ditampilkan pada Gambar 1 untuk peta tahun 2010 tercantum 0,3-0,4 g dan Gambar 2 untuk peta tahun 2017 tercantum $0,4-0,5 \mathrm{~g}$.

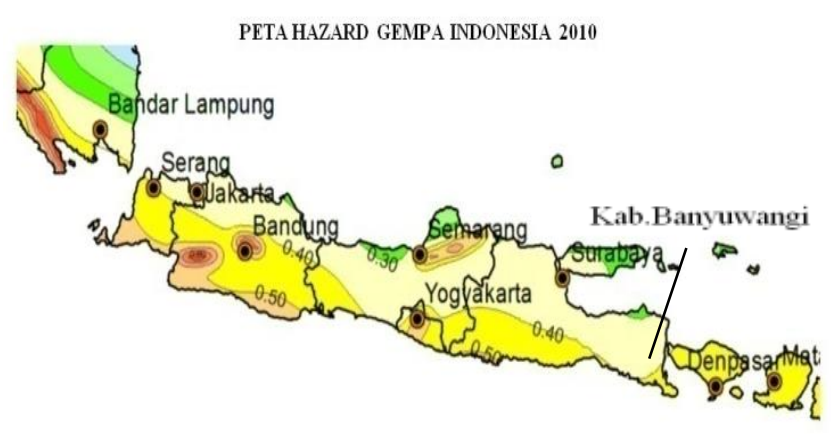

KETERANGAN :

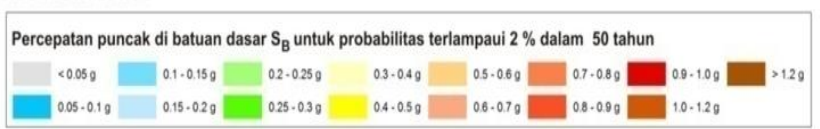

Gambar 1 Peta Hazard Gempa Indonesia 2010. Wilayah Kabupaten Banyuwangi

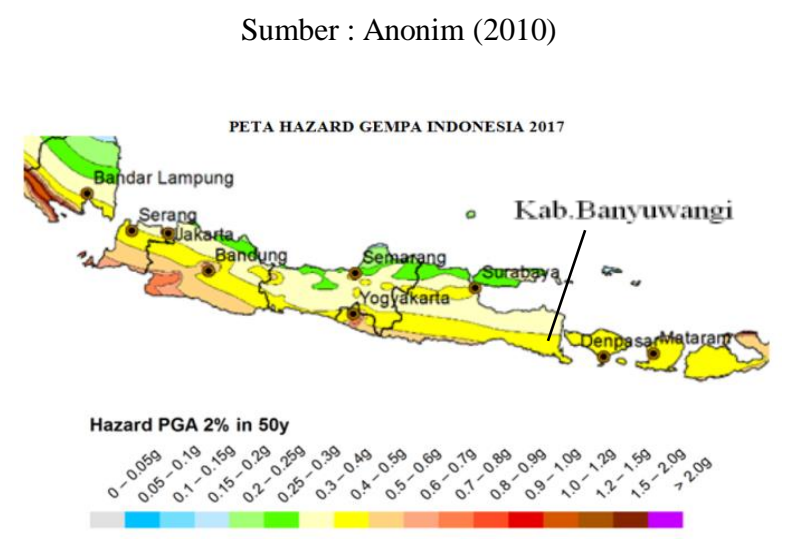

Gambar 2 Peta Hazard Gempa Indonesia 2017. Wilayah Kabupaten Banyuwangi. Sumber : Anonim (2017)

Dengan terjadinya perubahan pembebanan yang lebih besar di daerah Banyuwangi dari tahun 2010 ke 2017 maka perlu adanya penelitian lebih lanjut diambillah topik jurnal ini yaitu Pengaruh Revisi Peta Hazard Gempa Indonesia Terhadap Perencanaan Perkuatan Lereng Menggunakan Angkur.

\section{Pemilihan Parameter Perencanaan Angkur}

Hasil pemilihan parameter perencanaan angkur berdasarkan penelitian sebelumnya disajikan pada Tabel 1 .

Tabel 1 Penelitian Terdahulu

\begin{tabular}{|c|c|c|}
\hline PENELITI & \multicolumn{2}{|c|}{ URAIAN } \\
\hline \multirow{3}{*}{$\begin{array}{c}\text { Hanindya } \\
\text { Kusuma Artati } \\
\text { (2001) }\end{array}$} & Tinggi lereng $(\mathrm{H})$ & $30 \mathrm{ft}$ \\
\hline & Panjang angkur terbaik (L) & $24 \mathrm{ft}(\mathrm{L} / \mathrm{H}=0,8)$ \\
\hline & Sudut Angkur terbaik $(\theta)$ & $5^{\circ}$ \\
\hline \multirow{3}{*}{$\begin{array}{c}\text { Heri Syaeful dan } \\
\text { June Mellawati } \\
(2013)\end{array}$} & Tinggi lereng $(\mathrm{H})$ & $44 \mathrm{~m}$ \\
\hline & Jarak Vertikal (Sv) & $1,25 \mathrm{~m}$ \\
\hline & Sudut Angkur $(\theta)$ & $40^{\circ}$ \\
\hline \multirow{3}{*}{$\begin{array}{c}\text { Subriadi Subri } \\
\text { (2013) }\end{array}$} & Tinggi lereng $(\mathrm{H})$ & $7 \mathrm{~m}$ \\
\hline & Panjang Angkur (L) & $\begin{array}{l}9-11 \mathrm{~m} \\
(\mathrm{~L} / \mathrm{H}=1,3-1,6)\end{array}$ \\
\hline & Kapasitas Kekuatan & $60 \mathrm{Kn}$ \\
\hline
\end{tabular}

Sumber : Analisis data (2018)

Berdasarkan RSNI 3 Persyaratan Perancangan Geoteknik (2017) disyaratkan sudut kemiringan angkur berkisar antara $30^{\circ}-45^{\circ}$.

\section{METODOLOGI}

Penelitian ini dilakukan dengan menggunakan program komputer Rocsience Slide 6.0 dan perhitungan manual. Program Rocsience Slide 6.0 digunakan untuk menghitung stabilitas eksternal (overell) sedangkan perhitungan manual digunakan untuk menghitung stabilitas internal dan stabilitas terhadap kegagalan daya dukung tanah. Variasi penelitian yang digunakan antara lain variasi sudut kemiringan angkur $(\theta)=30^{\circ}, 40^{\circ}, 45^{\circ}$, rasio panjang perkuatan dan tinggi lereng $(\mathrm{L} / \mathrm{H})=0,6 ., 0,8$, 1 dan jarak vertikal antar perkuatan $(\mathrm{Sv})=2 \mathrm{~m}$.

Geometri model lereng yang digunakan pada penelitian ini di sajikan pada Gamabr 3 dan Gambar 4. 


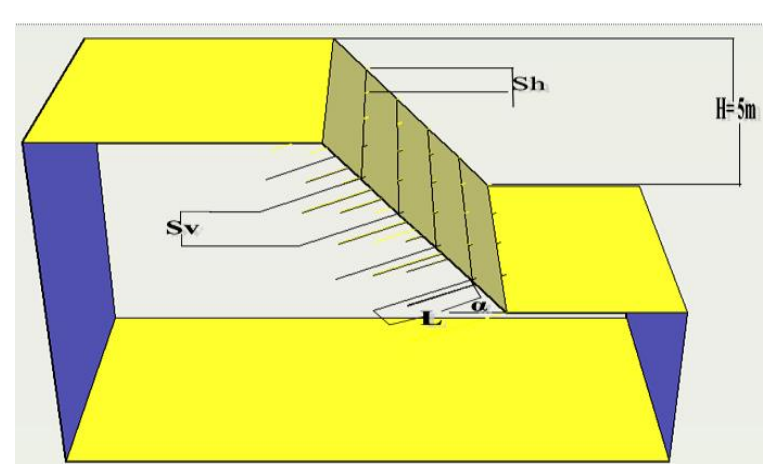

Gambar 3 Geometri Lereng

Sumber : Analisis data (2018)

Keterangan :

$\mathrm{H}=$ tinggi lereng $(\mathrm{m})$

$\mathrm{L}=$ panjang perkuatan angkur

$\theta=$ sudut kemiringan angkur $\left({ }^{\circ}\right)$

$\alpha=$ sudut kemiringan lereng $\left({ }^{\circ}\right)$

$\mathrm{Sh}=$ jarak horizontal antar perkuatan $(\mathrm{m})$

$\mathrm{Sv}=$ jarak vertikal antar perkuatan $(\mathrm{m})$

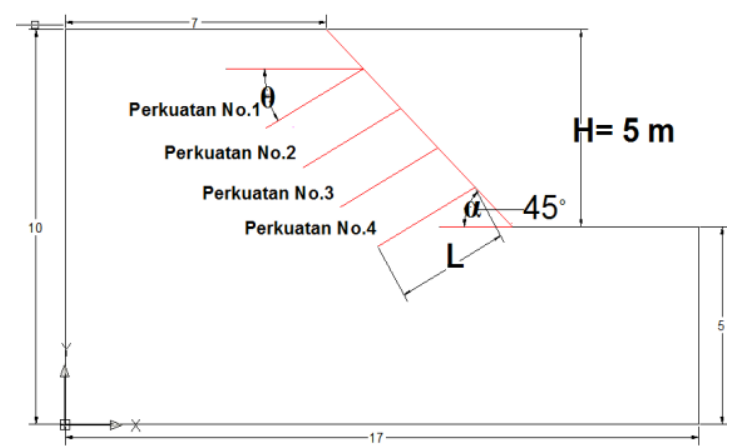

Gambar 4 Penomoran Perkuatan Lereng

Sumber : Analisis data (2018)

Keterangan :

$\mathrm{H}=$ tinggi lereng $(\mathrm{m})$

$\mathrm{L}=$ panjang perkuatan angkur

$\theta=$ sudut kemiringan angkur $\left({ }^{\circ}\right)$

$\alpha=$ sudut kemiringan lereng $\left({ }^{\circ}\right)$

Alternatif pemasangan ini dilakukan dengan cara: rancangan perkuatan angkur daerah Kab. Banyuwagi meliputi sudut kemiringan, panjang angkur, beban gempa, dan terakhir menentukan faktor keamanan. Variasi penelitian disajikan pada Tabel 2.

Tabel 2 Variabel Penelitian

\begin{tabular}{|c|c|c|c|c|}
\hline $\mathrm{Sv}(\mathrm{m})$ & $\theta^{\circ}$ & $\mathrm{L} / \mathrm{H}$ & $\begin{array}{c}\text { Beban } \\
\text { Gempa } \\
2010\end{array}$ & $\begin{array}{c}\text { Beban } \\
\text { Gempa } \\
2017\end{array}$ \\
\hline \multirow[t]{9}{*}{$2 \mathrm{~m}$} & \multirow{3}{*}{$30^{\circ}$} & 0,6 & & \\
\hline & & 0,8 & & \\
\hline & & 1 & & \\
\hline & \multirow{3}{*}{$40^{\circ}$} & 0,6 & & \\
\hline & & 0,8 & & \\
\hline & & 1 & & \\
\hline & \multirow{3}{*}{$45^{\circ}$} & 0,6 & & \\
\hline & & 0,8 & & \\
\hline & & 1 & & \\
\hline
\end{tabular}

Sumber : Analisis data (2018)

\section{Properti Tanah dan Perkuatan}

Parameter data tanah yang digunakan adalah berat volume tanah, kohesi, sudut geser dalam, kemiringan lereng, dan kapasitas angkur. Kelas situs diasumsikan tanah sedang (SD). Parameter tanah dan perkuatan disajikan pada Tabel 3 .

Tabel 3 Parameter tanah dan perkuatan

\begin{tabular}{cc}
\hline Parameter & Satuan \\
\hline Berat Volume Tanah $(\gamma)$ & $17 \mathrm{kN} / \mathrm{m}^{3}$ \\
\hline Kohesi $(\mathrm{c})$ & $10 \mathrm{kN} / \mathrm{m}^{2}$ \\
\hline Sudut Geser Dalam $(\varphi)$ & $30^{\circ}$ \\
\hline Kapasitas Angkur $(\mathrm{Ta})$ & $60 \mathrm{kN}$ \\
\hline Bond Strenght & $50 \mathrm{kN} / \mathrm{m}$ \\
\hline Jarak Horizontal Antar Angkur $(\mathrm{Sh})$ & $1 \mathrm{~m}$ \\
\hline
\end{tabular}

Sumber : Analisis data (2018)

Diagram alir penelitian yang akan dilakukan seperti yang ditampilkan pada Gambar 5.

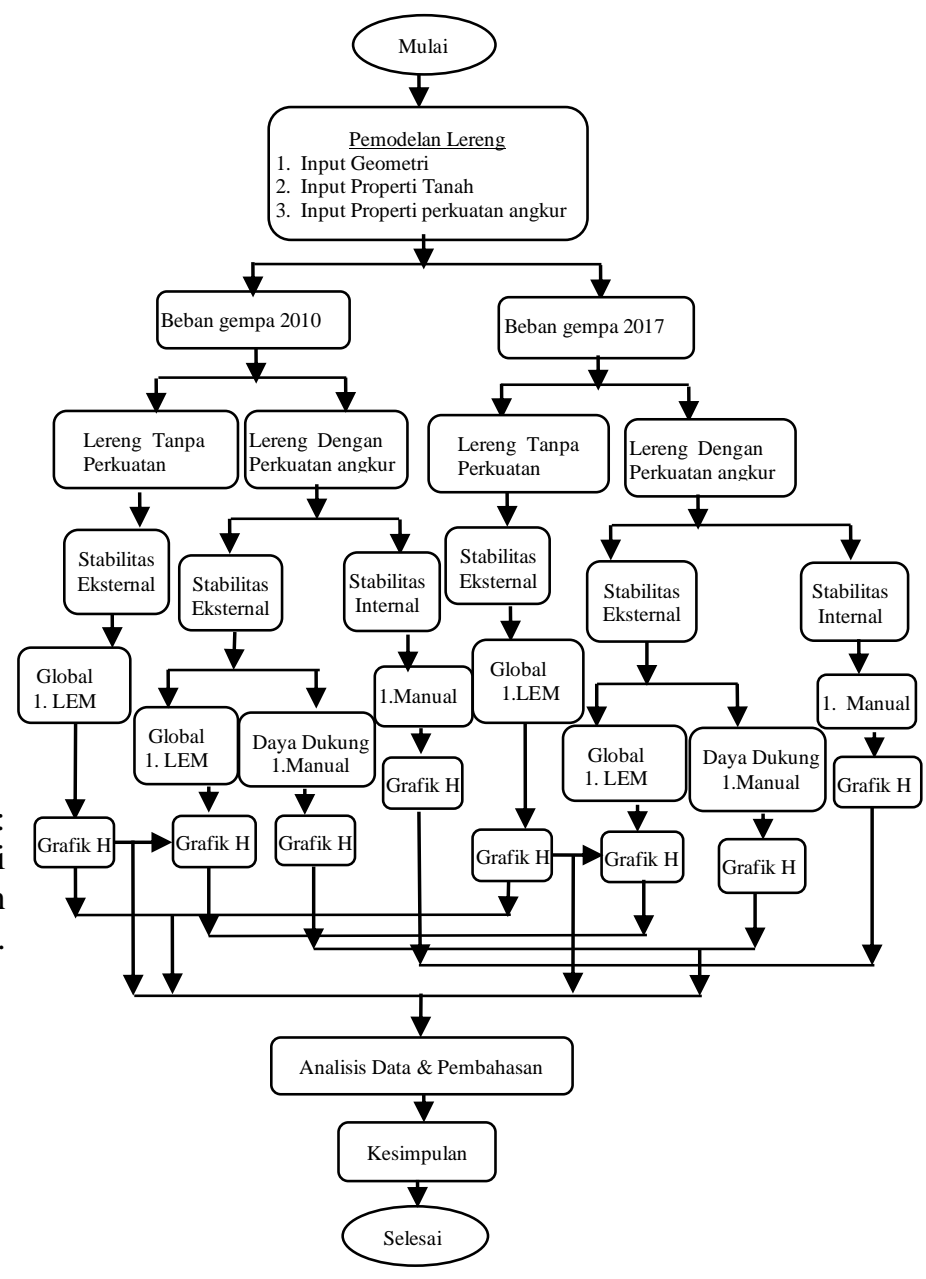

Gambar 5 Diagram Alir Penelitian Sumber : Analisis data (2018) 


\section{HASIL PENELITIAN DAN PEMBAHASAN} Penentuan Koefisien Seismik Horizontal

1) Perhitungan Koefisien Seismik Horizontal (kh)

$>$ Menentukan percepatan tanah puncak yang disesuaikan dengan pengaruh klasifikasi situs F $_{\text {PGA }}$ pada Tabel 4 .

Tabel 4 Koefisien Situs FPGA

\begin{tabular}{cccccc}
\hline Kelas Situs & PGA $\leq 0,1$ & PGA $\leq 0,2$ & PGA $\leq 0,3$ & PGA $\leq 0,4$ & PGA $\leq 0,5$ \\
\hline SA & 0,8 & 0,8 & 0,8 & 0,8 & 0,8 \\
\hline SB & 1,0 & 1,0 & 1,0 & 1,0 & 1,0 \\
\hline SC & 1,2 & 1,2 & 1,1 & 1,0 & 1,0 \\
\hline SD & 1,6 & 1,4 & 1,2 & 1,1 & 1,0 \\
\hline SE & 2,5 & 1,7 & 1,2 & 0,9 & 0,9 \\
\hline SF & & Lihat 6.9 & & \\
\hline
\end{tabular}

Sumber : Anonim (2012)

Perolehan kelas situs SD ( tanah sedang ) :

$>$ Beban gempa tahun 2010, $\mathrm{PGA}=0,4=1,1$

$>$ Beban gempa tahun 2017, $\mathrm{PGA}=0,5=1,0$

2) Perhitungan $\mathrm{PGA}_{M} 0,4$

$$
\begin{aligned}
\mathrm{PGA}_{\mathrm{M}} & =\mathrm{F}_{\mathrm{PGA}} \times \mathrm{PGA} \\
& =1,1 \times 0,4=0,44 \mathrm{~g}
\end{aligned}
$$

3) Perhitungan $\mathrm{PGA}_{M} 0,5$

$$
\begin{aligned}
\mathrm{PGA}_{\mathrm{M}} & =\mathrm{F}_{\mathrm{PGA}} \times \mathrm{PGA} \\
& =1,1 \times 0,5=0,5 \mathrm{~g}
\end{aligned}
$$

4) Penentuan koefisien horizontal (kh) : 0,5 $\times \frac{\text { PGAM }}{g}$
Tahun $2010=0,5 \times \frac{0,44 \mathrm{~g}}{g}=0,22$

Tahun $2010=0,5 \times \frac{0,44 \mathrm{~g}}{\mathrm{~g}}=0,22$

Tahun $2017=0,5 \times \frac{0,5 \mathrm{~g}}{g}=0,25$

Berdasarkan perhitungan di atas diperoleh beban gempa tahun 2010 sebesar $\mathrm{kh}=0,22$ sedangkan pada tahun 2017 sebesar 0,25.

\section{Analisis tanpa perkuatan Slide 6.0 Beban Gempa} Tahun 2010 dan Tahun 2017

Analisis stabilitas lereng tanpa perkuatan yang menggunakan beban gempa 2010 dengan kh 0,22 didapatkan hasil perhitungan bidang longsor untuk model lereng dengan kemiringan $45^{\circ}$ ditunjukkan pada Gambar 6 . Faktor keamanan dihitung menggunakan bantuan program Rocsience Slide 6.0. Faktor keamanan pada kelongsoran yang diperoleh pada lereng tersebut sebesar 1,278. Sedangkan beban gempa 2017 dengan kh 0,25 ditunjukkan pada Gambar 7. Faktor keamanan dihitung menggunakan bantuan program Rocsience Slide 6.0. Faktor keamanan pada kelongsoran yang diperoleh pada lereng tersebut sebesar 1,228 .

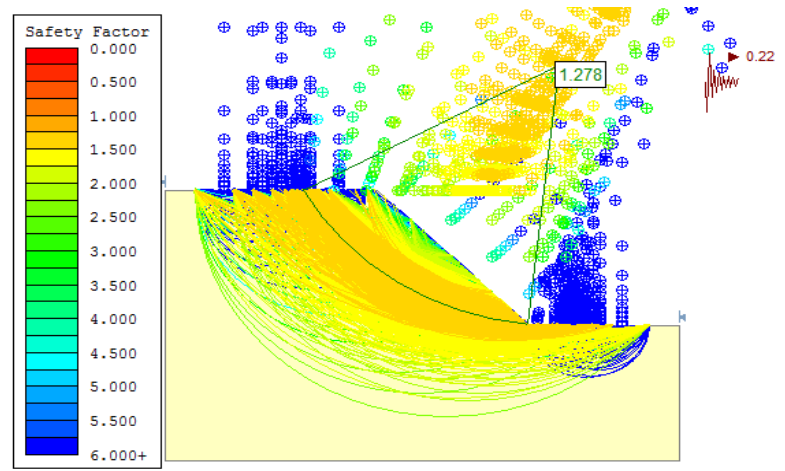

Gambar 6 Hasil perhitungan Slide 6.0 untuk lereng tanpa perkuatan dengan $\mathrm{kh}=0,22$.

Sumber : Analisis data (2018)

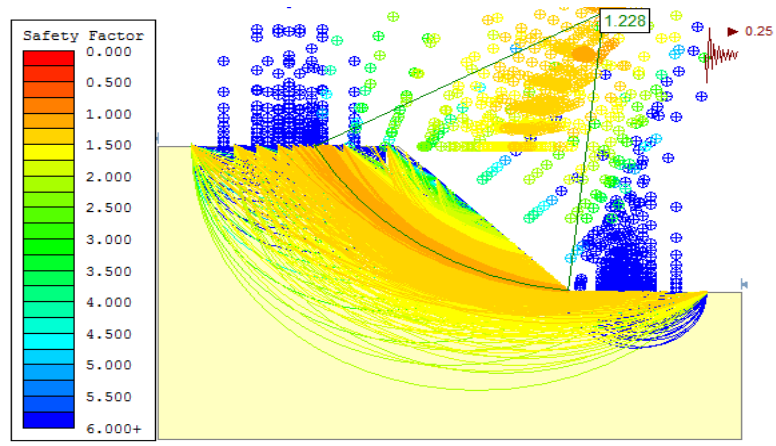

Gambar 7 Hasil perhitungan Slide 6.0 untuk lereng tanpa perkuatan dengan $\mathrm{kh}=0,25$.

Sumber : Analisis data (2018)

Hasil perhitungan stabilitas tanpa perkuatan dari beban gempa tahun $2010 \mathrm{kh}=0,22$ dan tahun $2017 \mathrm{kh}=0,25$ disajikan pada Tabel 5 dan Gambar 8.

Tabel 5 Persentase Stabilitas Lereng Tanpa Perkuatan

\begin{tabular}{cc}
\hline Beban Gempa (kh) & FS Tanpa Perkuatan \\
\cline { 2 - 2 } & Slide 6.0 (Bishop) \\
\hline 0,22 & 1,278 \\
\hline 0,25 & 1,228 \\
\hline $\begin{array}{c}\text { Prosentase Penurunan FS } \\
(\%)\end{array}$ & 3,9 \\
\hline
\end{tabular}

Sumber : Analisis data (2018)

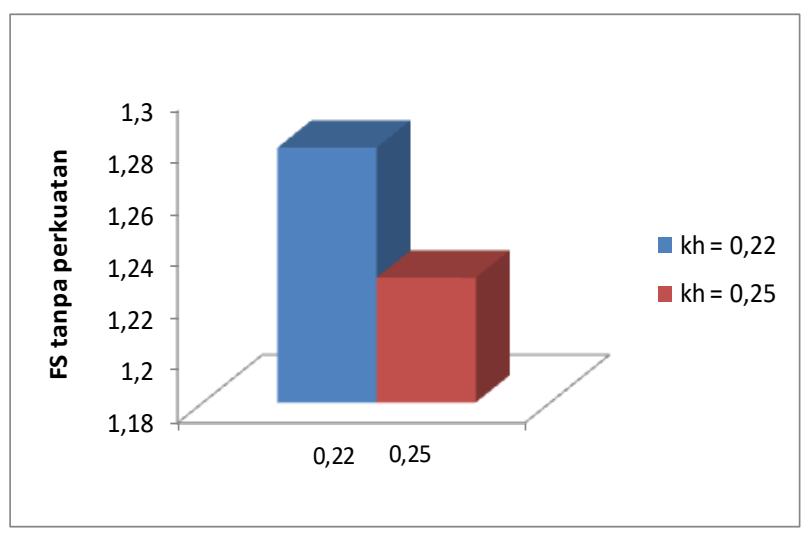

Gambar 8 Grafik hubungan FS tanpa perkuatan Vs koefisien horizontal (kh) beban gempa.

Sumber : Analisis data (2018) 
Dari Gambar 8 hubungan FS terhadap beban gempa (kh) dapat di analisa sebagai berikut :

1. Hubungan antara FS tanpa perkuatan terhadap beban gempa, tampak pada perhitungan yang sama yaitu cara program Slide 6.0 besarnya FS tahun $2010 \mathrm{kh}=0,22$ lebih besar dari FS tahun $2017 \mathrm{kh}=0,25$. Hal ini disebabkan semakin besar nilai beban gempa (kh) pada tahun 2017 maka nilai moment dorong juga semakin besar, sehingga dampak terhadap FS tahun 2017 kh= 0,25 semakin kecil.

\section{Analisis Lereng Dengan Perkuatan Angkur} Stabilitas Internal Angkur (Putus Tulangan dan Cabut Tulangan $\mathrm{kh}=0,22$ dan $\mathrm{kh}=\mathbf{0 , 2 5}$ )

a. Grafik FS putus tulangan $\left(\mathrm{FS}_{\mathrm{Fr}}\right) \theta=30^{\circ}, \mathrm{Sv}=2 \mathrm{~m}$

Hasil perhitungan penurunan persentase FS terhadap putus tulangan yang di pengaruhi oleh perubahan beban gempa tahun $2010 \mathrm{kh}=0,22$ dan tahun $2017 \mathrm{kh}=0,25$ dapat kita lihat pada Tabel 6 dan Gambar 9

Tabel 6 Penurunan perhitungan faktor keamanan terhadap putus tulangan $\left(\mathrm{FS}_{\mathrm{Fr}}\right)$ untuk $\theta=30^{\circ}$ dan $\mathrm{Sv}=2 \mathrm{~m}$

\begin{tabular}{|c|c|c|c|c|c|c|}
\hline \multirow{2}{*}{$\theta$} & \multirow{2}{*}{ SV } & \multirow{2}{*}{$\mathrm{L} / \mathrm{H}$} & \multirow{2}{*}{$\begin{array}{c}\text { No } \\
\text { perkuatan }\end{array}$} & FSFr & FSFr & \multirow{2}{*}{$\begin{array}{c}\text { Penurunan } \\
\text { Persentase } \\
\text { FSFr }(\%) \\
\end{array}$} \\
\hline & & & & $\mathrm{kh}=0,22$ & $\mathrm{kh}=0,25$ & \\
\hline \multirow{6}{*}{30} & \multirow{6}{*}{$2 \mathrm{~m}$} & \multirow{2}{*}{0,6} & 1 & 2,6458 & 2,4080 & 9,0 \\
\hline & & & 2 & 1,6856 & 1,5308 & 9,2 \\
\hline & & \multirow{2}{*}{0,8} & 1 & 2,3138 & 2,1051 & 9,0 \\
\hline & & & 2 & 1,5444 & 1,4025 & 9,2 \\
\hline & & \multirow{2}{*}{1} & 1 & 2,0559 & 1,8818 & 8,5 \\
\hline & & & 2 & 1,4251 & 1,2998 & 8,8 \\
\hline
\end{tabular}

Sumber : Analisis data (2018)

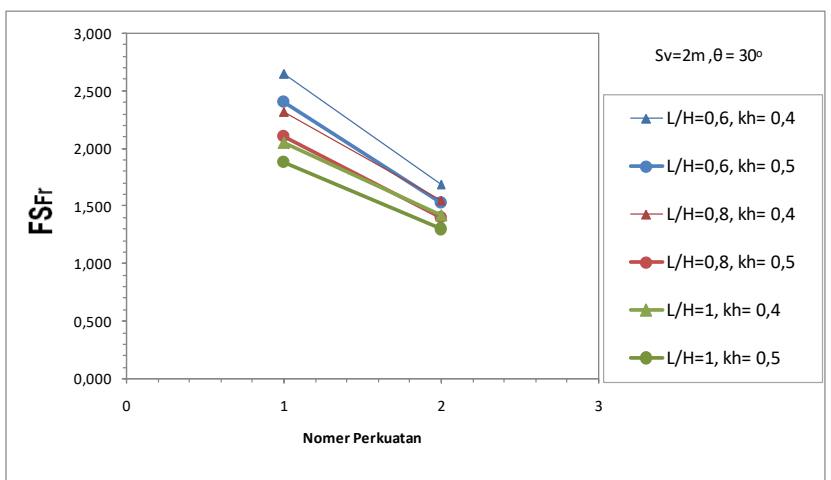

Gambar 9 Grafik FS putus tulangan $\left(\mathrm{FS}_{\mathrm{Fr}}\right)$ terhadap tiap no perkuatan angkur dengan $\theta=30^{\circ}, \mathrm{Sv}=2 \mathrm{~m}(\mathrm{kh}=0,22$ dan $\mathrm{kh}=0,25)$.

Sumber : Analisis data (2018)

Dari Gambar 9 dan Tabel 6 hubungan FS putus tulangan terhadap no.perkuatan dapat dianalisa sebagai berikut :

1) Tampak pada beban gempa tahun $2010 \mathrm{kh}=0,22$ dengan variasi sudut $(\theta)=30^{\circ}$, jarak vertikal $(\mathrm{sv})=2 \mathrm{~m}$ dan rasio panjang $(\mathrm{L} / \mathrm{H}=0,6, \mathrm{~L} / \mathrm{H}=0,8, \mathrm{~L} / \mathrm{H}=1)$ memiliki FS yang lebih besar dari pada beban gempa tahun $2017 \mathrm{kh}=0,25$. Hal ini dikerenakan adanya kenaikan nilai Ka pada beban gempa tahun 2017 yang menyebabkan FS putus tulangan semakin kecil.

2) Tampak pada beban gempa yang sama yaitu beban gempa tahun $2010 \mathrm{kh}=0,22$ dengan variasi $\mathrm{L} / \mathrm{H}=0,6$, $\mathrm{L} / \mathrm{H}=0,8$ dan $\mathrm{L} / \mathrm{H}=1$. Menunjukkan $\mathrm{FS} \mathrm{L} / \mathrm{H}=0,6$ memiliki FS tertinggi, hal ini disebabkan kecilnya nilai $\mathrm{Z}$ (kedalaman perkuatan ) pada panjang $\mathrm{L} / \mathrm{H}=0,6$ sehingga semakin kecil nilai $\mathrm{Z}$ (kedalaman perkuatan), semakin besar pula FS terhadap putus tulangan.

3) Tampak pada beban gempa yang sama yaitu beban gempa tahun $2017 \mathrm{kh}=0,25$ dengan variasi $\mathrm{L} / \mathrm{H}=0,6$, $\mathrm{L} / \mathrm{H}=0,8$ dan $\mathrm{L} / \mathrm{H}=1$. Menunjukkan $\mathrm{FS} \mathrm{L} / \mathrm{H}=0,6$ memiliki FS tertinggi, hal ini disebabkan kecilnya nilai $\mathrm{Z}$ (kedalaman perkuatan ) pada panjang $\mathrm{L} / \mathrm{H}=0,6$ sehingga semakin kecil nilai $\mathrm{Z}$ (kedalaman perkuatan), semakin besar pula FS terhadap putus tulangan.

b. Grafik FS putus tulangan $\left(\mathrm{FS}_{\mathrm{Fr}}\right) \theta=40^{\circ}, \mathrm{Sv}=2 \mathrm{~m}$

Hasil perhitungan penurunan persentase FS terhadap putus tulangan yang di pengaruhi oleh perubahan beban gempa tahun $2010 \mathrm{kh}=0,22$ dan tahun $2017 \mathrm{kh}=0,25$ dapat kita lihat pada Tabel 7 dan Gambar 10.

Tabel 7 Penurunan perhitungan faktor keamanan terhadap putus tulangan $\left(\mathrm{FS}_{\mathrm{Fr}}\right)$ untuk $\theta=40^{\circ}$ dan $\mathrm{Sv}=2 \mathrm{~m}$

\begin{tabular}{|c|c|c|c|c|c|c|}
\hline \multirow{2}{*}{$\theta$} & \multirow{2}{*}{ SV } & \multirow{2}{*}{$\mathrm{L} / \mathrm{H}$} & \multirow{2}{*}{$\begin{array}{c}\text { No } \\
\text { perkuatan }\end{array}$} & FSFr & FSFr & \multirow{2}{*}{$\begin{array}{c}\text { Penurunan } \\
\text { Persentase } \\
\text { FSFr(\%) }\end{array}$} \\
\hline & & & & $\mathrm{kh}=0,22$ & $\mathrm{kh}=0,25$ & \\
\hline \multirow{6}{*}{40} & \multirow{6}{*}{$2 \mathrm{~m}$} & \multirow{2}{*}{0,6} & 1 & 2,3644 & 2,1470 & 9,2 \\
\hline & & & 2 & 1,5668 & 1,4210 & 9,3 \\
\hline & & \multirow{2}{*}{0,8} & 1 & 2,0380 & 1,8467 & 9,4 \\
\hline & & & 2 & 1,4165 & 1,2829 & 9,4 \\
\hline & & \multirow{2}{*}{1} & 1 & 1,7894 & 1,6038 & 10,4 \\
\hline & & & 2 & 1,2917 & 1,1608 & 10,1 \\
\hline
\end{tabular}

Sumber : Analisis data (2018)

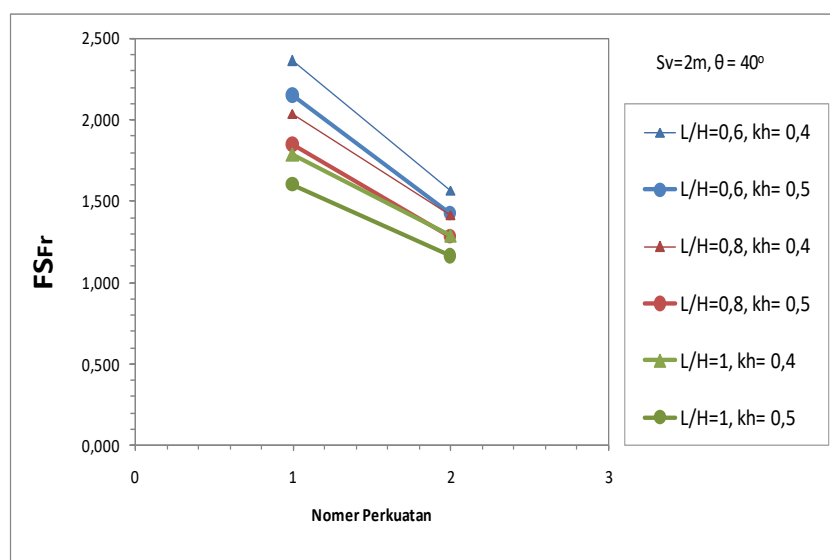

Gambar 10 Grafik FS putus tulangan $\left(\mathrm{Fs}_{\mathrm{Fr}}\right)$ terhadap tiap no perkuatan angkur dengan $\theta=40^{\circ}, \mathrm{Sv}=2 \mathrm{~m}(\mathrm{kh}=0,22$ dan $\mathrm{kh}=0,25)$. Sumber : Analisis data (2018) 
Dari Gambar 10 dan Tabel 7 hubungan FS putus tulangan terhadap no.perkuatan dapat dianalisa sebagai berikut :

1) Tampak pada beban gempa tahun $2010 \mathrm{kh}=0,22$ dengan variasi sudut $(\theta)=40^{\circ}$, jarak vertikal $(\mathrm{sv})=2 \mathrm{~m}$ dan rasio panjang $(\mathrm{L} / \mathrm{H}=0,6, \mathrm{~L} / \mathrm{H}=0,8, \mathrm{~L} / \mathrm{H}=1)$ memiliki FS yang lebih besar dari pada beban gempa tahun $2017 \mathrm{kh}=0,25$. Hal ini dikerenakan adanya kenaikan nilai Ka pada beban gempa tahun 2017 yang menyebabkan FS putus tulangan semakin kecil.

2) Tampak pada beban gempa yang sama yaitu beban gempa tahun $2010 \mathrm{kh}=0,22$ dengan variasi $\mathrm{L} / \mathrm{H}=0,6$, $\mathrm{L} / \mathrm{H}=0,8$ dan $\mathrm{L} / \mathrm{H}=1$. Menunjukkan $\mathrm{FS} \mathrm{L} / \mathrm{H}=0,6$ memiliki FS tertinggi, hal ini disebabkan kecilnya nilai $\mathrm{Z}$ (kedalaman perkuatan ) pada panjang $\mathrm{L} / \mathrm{H}=0,6$ sehingga semakin kecil nilai $\mathrm{Z}$ (kedalaman perkuatan), semakin besar pula FS terhadap putus tulangan.

3) Tampak pada beban gempa yang sama yaitu beban gempa tahun $2017 \mathrm{kh}=0,25$ dengan variasi $\mathrm{L} / \mathrm{H}=0,6$, $\mathrm{L} / \mathrm{H}=0,8$ dan $\mathrm{L} / \mathrm{H}=1$. Menunjukkan $\mathrm{FS} \mathrm{L} / \mathrm{H}=0,6$ memiliki FS tertinggi, hal ini disebabkan kecilnya nilai $\mathrm{Z}$ (kedalaman perkuatan ) pada panjang $\mathrm{L} / \mathrm{H}=0,6$ sehingga semakin kecil nilai $\mathrm{Z}$ (kedalaman perkuatan), semakin besar pula FS terhadap putus tulangan.

c. Grafik FS putus tulangan $\left(\mathrm{Fs}_{\mathrm{Fr}}\right) \theta=45^{\circ}, \mathrm{Sv}=2 \mathrm{~m}$

Hasil perhitungan penurunan persentase FS terhadap putus tulangan yang di pengaruhi oleh perubahan beban gempa tahun $2010 \mathrm{kh}=0,22$ dan tahun $2017 \mathrm{kh}=0,25$ dapat kita lihat pada Tabel 8 dan Gambar 11.

Tabel 8 Penurunan perhitungan faktor keamanan terhadap putus tulangan $\left(\mathrm{Fs}_{\mathrm{Fr}}\right)$ untuk $\theta=45^{\circ}$ dan $\mathrm{Sv}=2 \mathrm{~m}$

\begin{tabular}{|c|c|c|c|c|c|c|}
\hline \multirow{2}{*}{$\theta$} & \multirow{2}{*}{ SV } & \multirow{2}{*}{$\mathrm{L} / \mathrm{H}$} & \multirow{2}{*}{$\begin{array}{l}\text { No } \\
\text { perkuatan }\end{array}$} & FSFr & FSFr & \multirow{2}{*}{$\begin{array}{c}\text { Penurunan } \\
\text { Persentase } \\
\text { FSFr }(\%)\end{array}$} \\
\hline & & & & $\mathrm{kh}=0,22$ & $\mathrm{kh}=0,25$ & \\
\hline \multirow{6}{*}{45} & \multirow{6}{*}{$2 \mathrm{~m}$} & \multirow{2}{*}{0,6} & 1 & 2,2567 & 2,0477 & 9,2615 \\
\hline & & & 2 & 1,5188 & 1,3768 & 9,3474 \\
\hline & & \multirow{2}{*}{0,8} & 1 & 1,9239 & 1,7341 & 9,8636 \\
\hline & & & 2 & 1,3604 & 1,2276 & 9,7644 \\
\hline & & \multirow{2}{*}{1} & 1 & 1,6775 & 1,5220 & 9,2698 \\
\hline & & & 2 & 1,2327 & 1,1173 & 9,3566 \\
\hline
\end{tabular}

Sumber : Analisis data (2018)

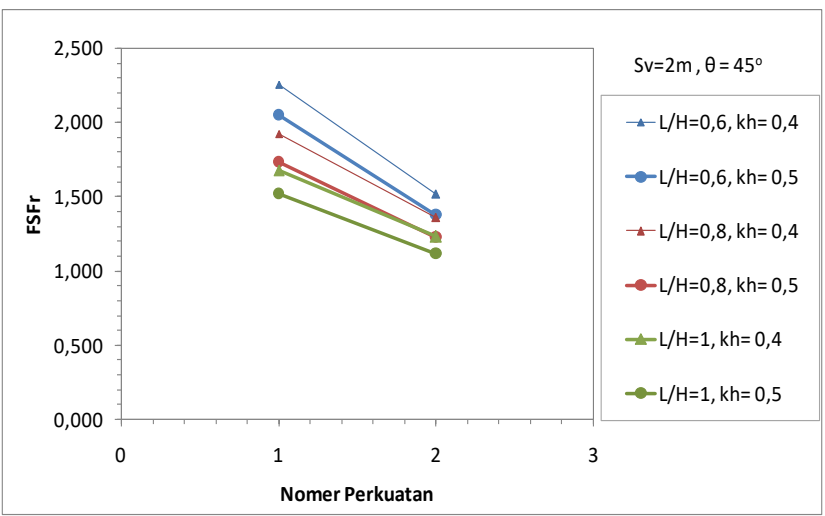

Gambar 11 Grafik FS putus tulangan $\left(\mathrm{FS}_{\mathrm{Fr}}\right)$ terhadap tiap no perkuatan angkur dengan $\theta=45^{\circ}, \mathrm{Sv}=2 \mathrm{~m}(\mathrm{kh}=0,22$ dan $\mathrm{kh}=0,25)$

Sumber : Analisis data (2018)

Dari Gambar 11 dan Tabel 8 hubungan FS putus tulangan terhadap no.perkuatan dapat dianalisa sebagai berikut :

1) Tampak pada beban gempa tahun $2010 \mathrm{kh}=0,22$ dengan variasi sudut $(\theta)=45^{\circ}$, jarak vertikal $(\mathrm{sv})=2 \mathrm{~m}$ dan rasio panjang $(\mathrm{L} / \mathrm{H}=0,6, \mathrm{~L} / \mathrm{H}=0,8, \mathrm{~L} / \mathrm{H}=1)$ memiliki FS yang lebih besar dari pada beban gempa tahun $2017 \mathrm{kh}=0,25$. Hal ini dikerenakan adanya kenaikan nilai Ka pada beban gempa tahun 2017 yang menyebabkan FS putus tulangan semakin kecil.

2) Tampak pada beban gempa yang sama yaitu beban gempa tahun $2010 \mathrm{kh}=0,22$ dengan variasi $\mathrm{L} / \mathrm{H}=0,6$, $\mathrm{L} / \mathrm{H}=0,8$ dan $\mathrm{L} / \mathrm{H}=1$. Menunjukkan $\mathrm{FS} \mathrm{L} / \mathrm{H}=0,6$ memiliki FS tertinggi, hal ini disebabkan kecilnya nilai Z (kedalaman perkuatan ) pada panjang $\mathrm{L} / \mathrm{H}=0,6$ sehingga semakin kecil nilai $\mathrm{Z}$ (kedalaman perkuatan), semakin besar pula FS terhadap putus tulangan.

3) Tampak pada beban gempa yang sama yaitu beban gempa tahun $2017 \mathrm{kh}=0,25$ dengan variasi $\mathrm{L} / \mathrm{H}=0,6$, $\mathrm{L} / \mathrm{H}=0,8$ dan $\mathrm{L} / \mathrm{H}=1$. Menunjukkan $\mathrm{FS} \mathrm{L} / \mathrm{H}=0,6$ memiliki FS tertinggi, hal ini disebabkan kecilnya nilai Z (kedalaman perkuatan ) pada panjang $\mathrm{L} / \mathrm{H}=0,6$ sehingga semakin kecil nilai $\mathrm{Z}$ (kedalaman perkuatan), semakin besar pula FS terhadap putus tulangan.

d. d. Grafik FS cabut tulangan $\left(\mathrm{FS}_{\mathrm{Fp}}\right) \theta=30^{\circ}, \mathrm{Sv}=2 \mathrm{~m}$

Hasil perhitungan penurunan persentase FS terhadap cabut tulangan yang di pengaruhi oleh perubahan beban gempa tahun $2010 \mathrm{kh}=0,22$ dan tahun $2017 \mathrm{kh}=0,25$ dapat kita lihat pada Tabel 9 dan Gambar 12. 
Tabel 9 Penurunan perhitungan faktor keamanan terhadap cabut tulangan $\left(\mathrm{Fs}_{\mathrm{Fp}}\right)$ untuk $\theta=30^{\circ}$ dan $\mathrm{Sv}=2 \mathrm{~m}$

\begin{tabular}{|c|c|c|c|c|c|c|}
\hline \multirow{2}{*}{$\theta$} & \multirow{2}{*}{ SV } & \multirow{2}{*}{$\mathrm{L} / \mathrm{H}$} & \multirow{2}{*}{$\begin{array}{c}\text { No } \\
\text { perkuatan }\end{array}$} & FSFp & FSFp & \multirow{2}{*}{$\begin{array}{c}\text { Penurunan } \\
\text { Persentase } \\
\text { FSFp (\%) }\end{array}$} \\
\hline & & & & $\mathrm{kh}=0,22$ & $\mathrm{kh}=0,25$ & \\
\hline \multirow{6}{*}{30} & \multirow{6}{*}{$2 \mathrm{~m}$} & \multirow{2}{*}{0,6} & 1 & 7,92757 & 7,15752 & 9,7 \\
\hline & & & 2 & 10,66078 & 9,64068 & 9,6 \\
\hline & & \multirow{2}{*}{0,8} & 1 & 14,64189 & 13,27829 & 9,3 \\
\hline & & & 2 & 14,91101 & 13,51472 & 9,4 \\
\hline & & \multirow{2}{*}{1} & 1 & 19,86408 & 18,11209 & 8,8 \\
\hline & & & 2 & 18,50583 & 16,83306 & 9,0 \\
\hline
\end{tabular}

Sumber : Analisis data (2018)

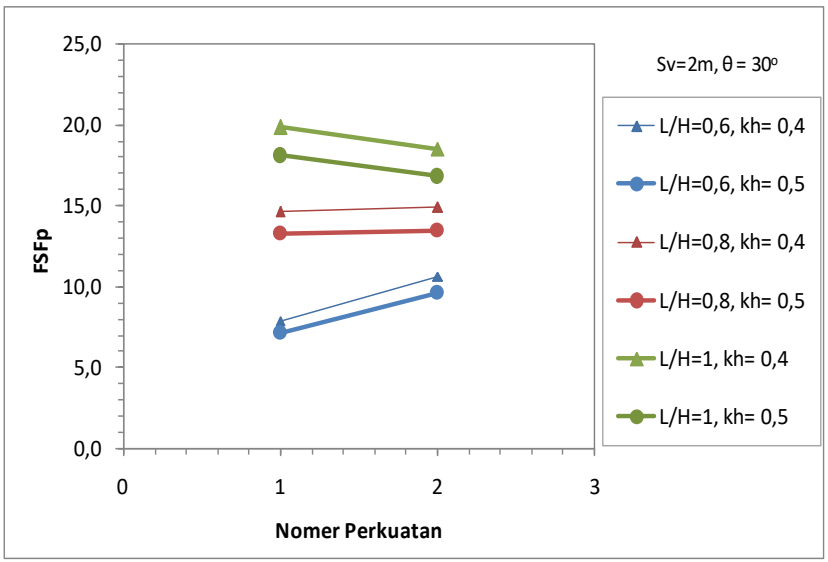

Gambar 12 Grafik FS cabut tulangan $\left(\mathrm{FS}_{\mathrm{Fp}}\right)$ terhadap tiap no perkuatan angkur dengan $\theta=30^{\circ}, \mathrm{Sv}=2 \mathrm{~m}(\mathrm{kh}=0,22$ dan $\mathrm{kh}=0,25)$

Sumber : Analisis data (2018)

Dari Gambar 12 dan Tabel 9 hubungan FS cabut tulangan terhadap no.perkuatan dapat dianalisa sebagai berikut :

1) Tampak pada beban gempa tahun $2010 \mathrm{kh}=0,22$ dengan variasi sudut $(\theta)=30^{\circ}$, jarak vertikal $(\mathrm{sv})=2 \mathrm{~m}$ dan rasio panjang $(\mathrm{L} / \mathrm{H}=0,6, \mathrm{~L} / \mathrm{H}=0,8, \mathrm{~L} / \mathrm{H}=1)$ memiliki FS yang lebih besar dari pada beban gempa tahun $2017 \mathrm{kh}=0,25$. Hal ini dikerenakan adanya kenaikan nilai Ka pada beban gempa tahun 2017 yang menyebabkan FS cabut tulangan semakin kecil.

2) Tampak pada beban gempa yang sama yaitu beban gempa tahun $2010 \mathrm{kh}=0,22$ dengan variasi $\mathrm{L} / \mathrm{H}=0,6$, $\mathrm{L} / \mathrm{H}=0,8$ dan $\mathrm{L} / \mathrm{H}=1$. Menunjukkan $\mathrm{FS} \mathrm{L} / \mathrm{H}=1$ memiliki FS tertinggi, hal ini disebabkan besarnya nilai Lo (panjang perkuatan di belakang garis longsor) pada panjang $\mathrm{L} / \mathrm{H}=1$ sehingga semakin besar nilai Lo, semakin besar pula FS terhadap cabut tulangan.

3) Tampak pada beban gempa yang sama yaitu beban gempa tahun $2010 \mathrm{kh}=0,22$ dengan variasi $\mathrm{L} / \mathrm{H}=0,6$, $\mathrm{L} / \mathrm{H}=0,8$ dan $\mathrm{L} / \mathrm{H}=1$. Menunjukkan $\mathrm{FS} \mathrm{L} / \mathrm{H}=1$ memiliki FS tertinggi, hal ini disebabkan besarnya nilai Lo (panjang perkuatan di belakang garis longsor) pada panjang $\mathrm{L} / \mathrm{H}=1$ sehingga semakin besar nilai Lo, semakin besar pula FS terhadap cabut tulangan. e. Grafik FS cabut tulangan $\left(\mathrm{Fs}_{\mathrm{Fp}}\right) \theta=40^{\circ}, \mathrm{Sv}=2 \mathrm{~m}$

Hasil perhitungan penurunan persentase FS terhadap cabut tulangan yang di pengaruhi oleh perubahan beban gempa tahun $2010 \mathrm{kh}=0,22$ dan tahun $2017 \mathrm{kh}=0,25$ dapat kita lihat pada Tabel 10 dan Gambar 13.

Tabel 10 Penurunan perhitungan faktor keamanan terhadap cabut tulangan $\left(\mathrm{FS}_{\mathrm{Fp}}\right)$ untuk $\theta=40^{\circ}$ dan $\mathrm{Sv}=2 \mathrm{~m}$

\begin{tabular}{|c|c|c|c|c|c|c|}
\hline \multirow[b]{2}{*}{$\theta$} & \multirow[b]{2}{*}{ SV } & \multirow[b]{2}{*}{$\mathrm{L} / \mathrm{H}$} & \multirow{2}{*}{$\begin{array}{c}\text { No } \\
\text { perkuatan }\end{array}$} & FSFp & FSFp & \multirow{2}{*}{$\begin{array}{c}\text { Penurunan } \\
\text { Persentase } \\
\text { FSFp (\%) }\end{array}$} \\
\hline & & & & $\mathrm{kh}=0,22$ & $\mathrm{kh}=0,25$ & \\
\hline \multirow{6}{*}{40} & \multirow{6}{*}{$2 \mathrm{~m}$} & \multirow{2}{*}{0,6} & 1 & 8,01282 & 7,25472 & 9,5 \\
\hline & & & 2 & 10,61709 & 9,61116 & 9,5 \\
\hline & & \multirow{2}{*}{0,8} & 1 & 13,68403 & 12,39129 & 9,4 \\
\hline & & & 2 & 14,30655 & 12,95703 & 9,4 \\
\hline & & \multirow{2}{*}{1} & 1 & 17,97605 & 16,14861 & 10,2 \\
\hline & & & 2 & 17,34664 & 15,62029 & 10,0 \\
\hline
\end{tabular}

Sumber : Analisis data (2018)

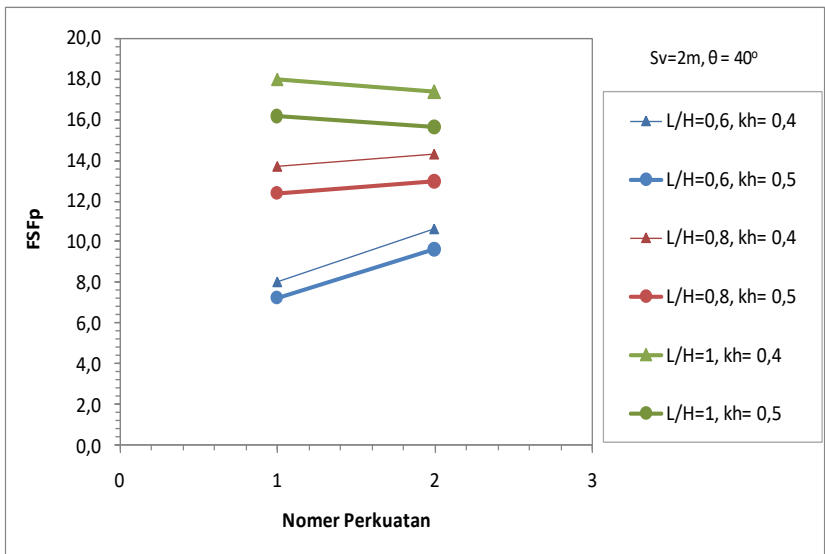

Gambar 13 Grafik FS cabut tulangan $\left(\mathrm{FS}_{\mathrm{Fp}}\right)$ terhadap tiap no perkuatan angkur dengan $\theta=40^{\circ}, \mathrm{Sv}=2 \mathrm{~m}(\mathrm{kh}=0,22$ dan $\mathrm{kh}=0,25)$. Sumber : Analisis data (2018)

Dari Gambar 13 dan Tabel 10 hubungan FS cabut tulangan terhadap no.perkuatan dapat dianalisa sebagai berikut :

1) Tampak pada beban gempa tahun $2010 \mathrm{kh}=0,22$ dengan variasi sudut $(\theta)=40^{\circ}$, jarak vertikal $(\mathrm{sv})=2 \mathrm{~m}$ dan rasio panjang $(\mathrm{L} / \mathrm{H}=0,6, \mathrm{~L} / \mathrm{H}=0,8, \mathrm{~L} / \mathrm{H}=1)$ memiliki FS yang lebih besar dari pada beban gempa tahun $2017 \mathrm{kh}=0,25$. Hal ini dikerenakan adanya kenaikan nilai Ka pada beban gempa tahun 2017 yang menyebabkan FS cabut tulangan semakin kecil.

2) Tampak pada beban gempa yang sama yaitu beban gempa tahun $2010 \mathrm{kh}=0,22$ dengan variasi $\mathrm{L} / \mathrm{H}=0,6$, $\mathrm{L} / \mathrm{H}=0,8$ dan $\mathrm{L} / \mathrm{H}=1$. Menunjukkan $\mathrm{FS} \mathrm{L} / \mathrm{H}=1$ memiliki FS tertinggi, hal ini disebabkan besarnya nilai Lo (panjang perkuatan di belakang garis longsor) pada panjang $\mathrm{L} / \mathrm{H}=1$ sehingga semakin besar nilai Lo, semakin besar pula FS terhadap cabut tulangan.

3) Tampak pada beban gempa yang sama yaitu beban gempa tahun $2010 \mathrm{kh}=0,22$ dengan variasi $\mathrm{L} / \mathrm{H}=0,6$, $\mathrm{L} / \mathrm{H}=0,8$ dan $\mathrm{L} / \mathrm{H}=1$. Menunjukkan $\mathrm{FS} \mathrm{L} / \mathrm{H}=1$ 
memiliki FS tertinggi, hal ini disebabkan besarnya nilai Lo (panjang perkuatan di belakang garis longsor) pada panjang $\mathrm{L} / \mathrm{H}=1$ sehingga semakin besar nilai Lo, semakin besar pula FS terhadap cabut tulangan.

f. Grafik FS cabut tulangan $\left(\mathrm{FS}_{\mathrm{Fp}}\right) \theta=45^{\circ}, \mathrm{Sv}=2 \mathrm{~m}$

Hasil perhitungan penurunan persentase FS terhadap cabut tulangan yang di pengaruhi oleh perubahan beban gempa tahun $2010 \mathrm{kh}=0,22$ dan tahun $2017 \mathrm{kh}=0,25$ dapat kita lihat pada Tabel 11 dan Gambar 14.

Tabel 11 Penurunan perhitungan faktor keamanan terhadap cabut tulangan $\left(\mathrm{Fs}_{\mathrm{Fp}}\right)$ untuk $\theta=45^{\circ}$ dan $\mathrm{Sv}=2 \mathrm{~m}$

\begin{tabular}{|c|c|c|c|c|c|c|}
\hline \multirow{2}{*}{$\theta$} & \multirow{2}{*}{ SV } & \multirow{2}{*}{$\mathrm{L} / \mathrm{H}$} & \multirow{2}{*}{$\begin{array}{c}\text { No } \\
\text { perkuatan }\end{array}$} & \multirow{2}{*}{$\begin{array}{c}\text { FSFp } \\
\mathrm{kh}=0,22\end{array}$} & \multirow{2}{*}{$\begin{array}{c}\text { FSFp } \\
\mathrm{kh}=0,25\end{array}$} & \multirow{2}{*}{$\begin{array}{l}\text { Penurunan } \\
\text { Persentase } \\
\text { FSFp (\%) }\end{array}$} \\
\hline & & & & & & \\
\hline \multirow{6}{*}{45} & \multirow{6}{*}{$2 \mathrm{~m}$} & \multirow{2}{*}{0,6} & 1 & 7,93533 & 7,18948 & 9,4 \\
\hline & & & 2 & 10,53271 & 9,53671 & 9,5 \\
\hline & & \multirow{2}{*}{0,8} & 1 & 13,18244 & 11,89547 & 9,8 \\
\hline & & & 2 & 13,97483 & 12,62256 & 9,7 \\
\hline & & \multirow{2}{*}{1} & 1 & 17,08859 & 15,49994 & 9,3 \\
\hline & & & 2 & 16,78094 & 15,19741 & 9,4 \\
\hline
\end{tabular}

Sumber : Analisis data (2018)

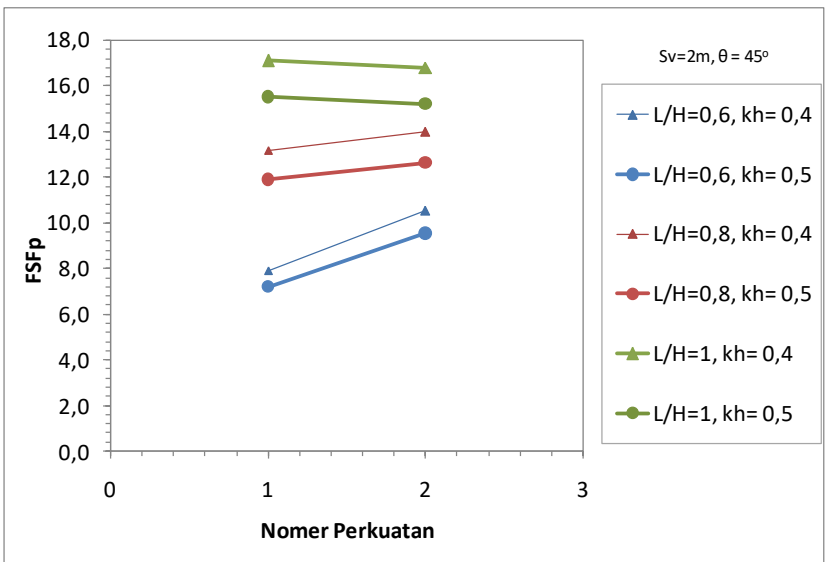

Gambar 14 Grafik FS cabut tulangan $\left(\mathrm{Fs}_{\mathrm{Fp}}\right)$ terhadap tiap no perkuatan angkur dengan $\theta=45^{\circ}, \mathrm{Sv}=2 \mathrm{~m}(\mathrm{kh}=0,22$ dan $\mathrm{kh}=0,25)$. Sumber : Analisis data (2018)

Dari Gambar 14 dan Tabel 11 hubungan FS cabut tulangan terhadap no.perkuatan dapat dianalisa sebagai berikut :

1) Tampak pada beban gempa tahun $2010 \mathrm{kh}=0,22$ dengan variasi sudut $(\theta)=45^{\circ}$, jarak vertikal $(\mathrm{sv})=2 \mathrm{~m}$ dan rasio panjang $(\mathrm{L} / \mathrm{H}=0,6, \mathrm{~L} / \mathrm{H}=0,8, \mathrm{~L} / \mathrm{H}=1)$ memiliki FS yang lebih besar dari pada beban gempa tahun $2017 \mathrm{kh}=0,25$. Hal ini dikerenakan adanya kenaikan nilai Ka pada beban gempa tahun 2017 yang menyebabkan FS cabut tulangan semakin kecil.

2) Tampak pada beban gempa yang sama yaitu beban gempa tahun $2010 \mathrm{kh}=0,22$ dengan variasi $\mathrm{L} / \mathrm{H}=0,6$, $\mathrm{L} / \mathrm{H}=0,8$ dan $\mathrm{L} / \mathrm{H}=1$. Menunjukkan $\mathrm{FS} \mathrm{L} / \mathrm{H}=1$ memiliki FS tertinggi, hal ini disebabkan besarnya nilai Lo (panjang perkuatan di belakang garis longsor) pada panjang $\mathrm{L} / \mathrm{H}=1$ sehingga semakin besar nilai Lo, semakin besar pula FS terhadap cabut tulangan.

3) Tampak pada beban gempa yang sama yaitu beban gempa tahun $2010 \mathrm{kh}=0,22$ dengan variasi $\mathrm{L} / \mathrm{H}=0,6$, $\mathrm{L} / \mathrm{H}=0,8$ dan $\mathrm{L} / \mathrm{H}=1$. Menunjukkan $\mathrm{FS} \mathrm{L} / \mathrm{H}=1$ memiliki FS tertinggi, hal ini disebabkan besarnya nilai Lo (panjang perkuatan di belakang garis longsor) pada panjang $\mathrm{L} / \mathrm{H}=1$ sehingga semakin besar nilai Lo, semakin besar pula FS terhadap cabut tulangan.

\section{Perhitungan Stabilitas Eksternal Angkur}

\section{Stabilitas Kegagalan Daya Dukung Tanah}

A. Grafik FS daya dukung tanah $\mathrm{Sv}=2 \mathrm{~m}(\mathrm{kh}=0,22$ dan $\mathrm{kh}=0,25)$

Hasil perhitungan penurunan persentase FS terhadap kegagalan daya dukung tanah yang dipengaruhi oleh perubahan beban gempa tahun $2010 \mathrm{kh}=0,22$ dan tahun $2017 \mathrm{kh}=0,25$ dapat kita lihat pada Tabel 12 dan Gambar 15 .

Tabel 12 Penurunan perhitungan faktor keamanan terhadap kegagalan daya dukung tanah $\mathrm{Sv}=2 \mathrm{~m}$

\begin{tabular}{|c|c|c|c|c|c|}
\hline \multirow{2}{*}{ Sv } & \multirow{2}{*}{$\theta$} & \multirow{2}{*}{$\mathrm{L} / \mathrm{H}$} & \multicolumn{2}{|c|}{ FS daya dukung } & \multirow{2}{*}{$\begin{array}{c}\text { Prosentase } \\
\text { Penurunan FS }(\%\end{array}$} \\
\hline & & & 0,22 & 0,25 & \\
\hline \multirow{9}{*}{$2 \mathrm{~m}$} & \multirow{3}{*}{$30^{\circ}$} & 0,6 & 13,9739 & 12,1240 & 13,2 \\
\hline & & 0,8 & 14,6650 & 12,6862 & 13,5 \\
\hline & & 1 & 15,3562 & 13,2589 & 13,7 \\
\hline & \multirow{3}{*}{$40^{\circ}$} & 0,6 & 13,7389 & 11,9330 & 13,1 \\
\hline & & 0,8 & 14,3609 & 12,4343 & 13,4 \\
\hline & & 1 & 14,9800 & 12,9070 & 13,8 \\
\hline & \multirow{3}{*}{$45^{\circ}$} & 0,6 & 13,6018 & 11,8215 & 13,1 \\
\hline & & 0,8 & 14,1636 & 12,2585 & 13,5 \\
\hline & & 1 & 14,7277 & 12,7387 & 13,5 \\
\hline
\end{tabular}

Sumber : Analisis data (2018)

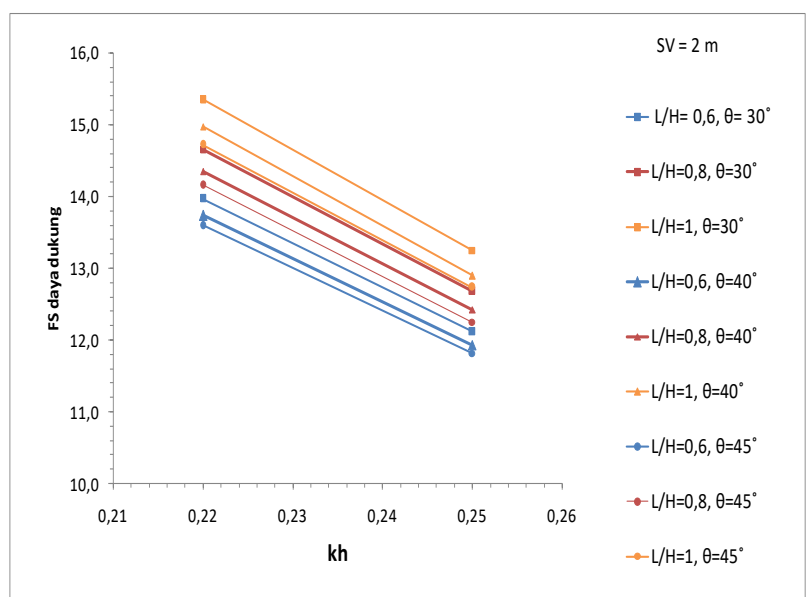

Gambar 15 Grafik FS daya dukung tanah dengan perkuatan angkur untuk $\mathrm{Sv}=2 \mathrm{~m}, \mathrm{kh}=0,22$ dan $\mathrm{kh}=0,25$ Sumber : Analisis data (2018) 
Dari Gambar 15 dan Tabel 12 hubungan FS daya dukung tanah terhadap panjang angkur dapat di analisa sebagai berikut :

1) Tampak pada beban gempa tahun $2010 \mathrm{kh}=0,22$ dan tahun $2017 \mathrm{kh}=0,25$. Menunjukkan FS daya dukung pada tahun 2010 lebih besar dari pada tahun 2017. Hal ini dikarenakan adanya penurunan nilai oult dimana nilai oult dipengaruhi oleh faktor kapasitas daya dukung ( $\mathrm{NcE}, \mathrm{NqE}, \mathrm{N} \gamma \mathrm{E}$ ) yang besarnya ditentukan berdasarkan koefisien gempa horizontal (kh). Semakin besar kh maka nilai faktor daya dukung dan nilai oult semakin meningkat yang menyebabkan FS akan menurun.

2) Tampak pada panjang angkur $(\mathrm{L} / \mathrm{H})=0,6 ., \mathrm{L} / \mathrm{H}=0,8$, $\mathrm{L} / \mathrm{H}=1$ dengan sudut angkur yang sama yaitu $\theta=30^{\circ}$ menunjukkan nilai tertinggi ada pada panjang angkur $\mathrm{L} / \mathrm{H}=1$, hal ini dikarenakan pada $\mathrm{L} / \mathrm{H}=1$ memiliki nilai B (daya dukung) yang besar, semakin besar nilai B maka FS terhadap kegagalan daya dukung akan semakin besar.

3) Tampak pada sudut angkur $\theta=30^{\circ}, \theta=40^{\circ}, \theta=45^{\circ}$ dengan panjang angkur yang sama yaitu $\mathrm{L} / \mathrm{H}=0,6$ menunjukkan nilai tertinggi ada pada sudut $\theta=30^{\circ}$, hal ini dikarenakan pada sudut $\theta=30^{\circ}$ memiliki nilai B yang besar, semakin besar nilai B maka FS terhadap kegagalan daya dukung akan semakin besar.

\section{Stabilitas Terhadap Keruntuhan Global}

A. Grafik FS keruntuhan Global $\mathrm{Sv}=2 \mathrm{~m}, \mathrm{kh}=0,22$ dan $\mathrm{kh}=0,25$

Hasil perhitungan penurunan persentase FS terhadap keruntuhan global yang dipengaruhi oleh perubahan beban gempa tahun $2010 \mathrm{kh}=0,22$ dan tahun $2017 \mathrm{kh}=0,25$ dapat kita lihat pada Tabel 13 dan Gambar 16.

Tabel 13 Penurunan perhitungan faktor keamanan terhadap keruntuhan global menggunakan Slide 6.0, variasi $\mathrm{Sv}=2 \mathrm{~m}$

\begin{tabular}{|c|c|c|c|c|c|}
\hline \multirow{3}{*}{ Sv } & \multirow{3}{*}{$\theta$} & \multirow{3}{*}{$\mathrm{L} / \mathrm{H}$} & \multicolumn{2}{|c|}{$\begin{array}{c}\text { FS keruntuhan global } \\
\text { (Slide) }\end{array}$} & \multirow{3}{*}{$\begin{array}{c}\text { Prosentase } \\
\text { Penurunan } \\
\text { FS }(\%)\end{array}$} \\
\hline & & & $\mathrm{kh}=0.22$ & $\mathrm{kh}=0.25$ & \\
\hline & & & Bishop & Bishop & \\
\hline \multirow{9}{*}{$2 \mathrm{~m}$} & \multirow{3}{*}{$30^{\circ}$} & 0,6 & 1,535 & 1,470 & 4,2 \\
\hline & & 0,8 & 1,655 & 1,579 & 4,6 \\
\hline & & 1 & 1,760 & 1,675 & 4,8 \\
\hline & \multirow{3}{*}{$40^{\circ}$} & 0,6 & 1,561 & 1,492 & 4,4 \\
\hline & & 0,8 & 1,722 & 1,625 & 5,6 \\
\hline & & 1 & 1,813 & 1,721 & 5,1 \\
\hline & \multirow{3}{*}{$45^{\circ}$} & 0,6 & 1,568 & 1,500 & 4,3 \\
\hline & & 0,8 & 1,710 & 1,626 & 4,9 \\
\hline & & 1 & 1,825 & 1,737 & 4,8 \\
\hline
\end{tabular}

Sumber : Analisis data (2018)

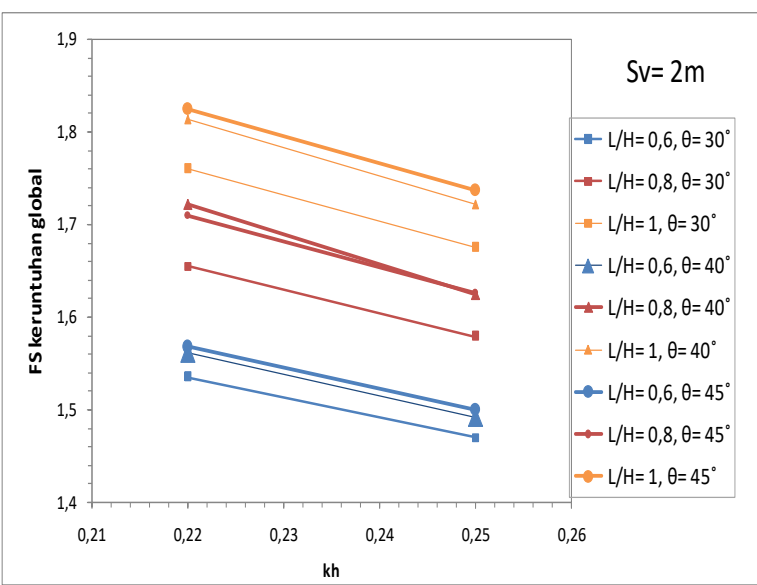

Gambar 16 Grafik FS keruntuhan global dengan perkuatan angkur untuk $\mathrm{Sv}=2 \mathrm{~m}, \mathrm{kh}=0,22$ dan $\mathrm{kh}=0,25$ Sumber : Analisis data (2018)

1) Tampak pada beban gempa tahun $2010 \mathrm{kh}=0,22$ dan tahun $2017 \mathrm{kh}=0$,25dengan menggunakan program Slide 6.0 besarnya FS kh=0,22 tahun 2010 lebih besar dari pada FS kh=0,25 tahun 2017. Hal ini dikarenakan semakin besarnya nilai beban gempa (kh) pada tahun 2017, sehingga semakin besar nilai beban gempa (kh) dampak terhadap FS akan semakin kecil.

\section{KESIMPULAN}

Berdasarkan dari pengolahan data yang di lakukan dengan program Slide 6.0 dan perhitungan manual maka di dapat hasil sebagaimana berikut:

Kesimpulan yang diperoleh dari penelitian ini yaitu :

1. Besarnya FS tanpa perkuatan dalam kondisi stabilitas eksternal menggunkan program Slide 6.0 beban gempa tahun $2017 \mathrm{kh}=0,25$ diperoleh FS sebesar 1,228 yang mengalami penurunan FS sebesar $3,9 \%$ jika dibandingkan dengan beban gempa tahun $2010 \mathrm{kh}=$ 0,22 dengan FS sebesar 1,278.

2. Besarnya FS pada lereng dengan perkuatan angkur dalam kondisi stabilitas internal tampak pada nilai FS putus tulangan tahun $2017(\mathrm{kh}=0,25)$ dengan variasi $\mathrm{Sv}=2 \mathrm{~m}, \theta=30^{\circ}, 40^{\circ}, 50^{\circ}$ dan $\mathrm{L} / \mathrm{H}=0,6, \mathrm{~L} / \mathrm{H}=0,8$ dan $\mathrm{L} / \mathrm{H}=1$ mengalami penurunan $\mathrm{FS}$ sebesar $8,5 \%$ $10,4 \%$ dari beban gempa tahun $2010 \quad(\mathrm{kh}=0,22)$. Sedangkan pada nilai FS cabut tulangan tahun 2017 $(\mathrm{kh}=0,25)$ dengan variasi $\mathrm{Sv}=2 \mathrm{~m}, \theta=30^{\circ}, 40^{\circ}, 45^{\circ}$ dan $\mathrm{L} / \mathrm{H}=0,6, \mathrm{~L} / \mathrm{H}=0,8, \mathrm{~L} / \mathrm{H}=1$ mengalami penurunan $\mathrm{FS}$ sebesar $8,8 \%$ - 10,2\% dari beban gempa tahun 2010 $(\mathrm{kh}=0,22)$.

3. Untuk stabilitas kegagalan daya dukung tanah tampak pada beban gempa tahun $2017 \mathrm{kh}=0,25$ dengan variasi $\theta=30^{\circ}, 40^{\circ}, 45^{\circ}, \mathrm{Sv}=2 \mathrm{~m}$ dan $\mathrm{L} / \mathrm{H}=0,6, \mathrm{~L} / \mathrm{H}=0,8, \mathrm{~L} / \mathrm{H}=1$ mengalami penurunan FS kuat dukung tanah sebesar $13,1 \%-13,8 \%$ dari beban gempa tahun $2010 \mathrm{kh}=0,22$.

4. Stabilitas keruntuhan global perhitungan FS menggunakan program Slide 6.0. tahun $2017 \mathrm{kh}=0,25$ 
dengan variasi $\theta=30^{\circ}, 40^{\circ}, 45^{\circ}, \mathrm{Sv}=2 \mathrm{~m}$ dan $\mathrm{L} / \mathrm{H}=0,6$, $\mathrm{L} / \mathrm{H}=0,8, \mathrm{~L} / \mathrm{H}=1$ mengalami penurunan $\mathrm{FS}$ sebesar $4,2 \%-5,6 \%$ dari beban gempa tahun $2010 \mathrm{kh}=0,22$.

\section{DAFTAR PUSTAKA}

Artati, Hanindya Kusuma, (2001). Analisis Perubahan Slip Surface Pada Penggunaan Perkuatan Angkur Dalam Sistem Stabilitas Lereng. Skripsi. Yogyakarta: Universitas Islam Indonesia.

Balitbang Kementrian PUPR.Pulau Jawa Siaga Gempa 7,5SR. Berita Even. 30 Mei. http://litbang.pu.go.id/arsip/pulau-jawa-siagagempa-75-sr/ (di akses 7 Oktober 2017)

Das, Braja M.,1941. Shallow foundations bearing capacity and settlement / Braja M. Das. -- 2nd ed. p. cm. Boca Raton London New York: CRC Press Taylor \& Francis Group.

Ebrahimi, Sarah, 2011. Extension of Mononobe Okabe Approach to Unstable Slope. PhDThesis. Newark: University of Delaware.

Hidayah, Susi., dan Gratia, Yohan Roy. 2007. Program Analisis Stabilitas. Tugas Akhir. Semarang : Universitas Diponegoro.

Hutama, Dio Alif, 2017. Validasi Grafik Desain Probabilitas Kestabilan Lereng menggunakan Slide 6. Jurnal Agregat. Vol.2, No.1: 7-13.

Isnaniati, 2017. Studi Komparatif Daya Dukung Pondasi Tiang Dengan Teori Meyerhoff Terhadap Teori L'Decourt Berdasar Hasil Uji N-SPT Di Surabaya Timur. Jurnal Agregat. Vol.2, No.2: 153-158.

K., Rama, Indera., Mina, Enden., dan B.,Suvenuary. 2015. Analisis stabilitas lereng dan perencanaan soilnailing dengan software Geostudio 2007. Jurnal Fondasi. 4 (1): (2-3).

Kementrian Pekerjaan Umum. 2010. Peta Hazard Gempa Indonesia 2010. https://orifis.files.wordpress.com (diakses 10 Oktober 2017)

Pramudhito, Ari., dan Karunia, Irsan Reza. 2013. Desain perkuatan Lereng Pada Sisi Kananlintasan Kereta Api KM.24+800 S.D.KM. 25+400 Antara Kalisetail-Kalibaru Lintas Surabaya-Banyuwangi, Daerah Oprasi 9 Jember. Skripsi. Bandung : Politeknik Negeri Bandung.

Putra, Tubagus Arisudana Widhya. 2017. Stabilitas Lereng Di Daerah Genangan Dalam Perencanaan Pembangunan Bendungan Logung Kabupaten Kudus, Jawa Tengah. Tugas Akhir. Semarang : Universitas Diponegoro.

Simatupang, Pintor Tua. 2004. Analisis Stabilitas Lereng Seismik dengan Metode Pseudostatik. Pertemuan ilmiah tahunan-VIII HATTI, Gd. Pusat Studi Jepang, Unieversitas Indonesia- Depok, 34Agustus.https://www.researchgate.net/publication/ 299092924. (di akses 6 Oktober 2017).

SNI Badan Standarisasi Nasional, 2012. Tata Cara Perencanaan Ketahanan Gempa Untuk Struktur Bangunan Gedung Dan Non Gedung. SNI 1726: 2012. Jakarta.

SNI Standar Nasional Indonesia, 2017. Persyaratan Perancangan Geoteknik. SNI 8460 : 2017. Jakarta.
Subri, Subriadi. 2013. Studi perkuatan lereng dengan software geoslope pada tanah lempung. Jurnal Tugas Akhir. Jurusan Teknik Sipil Fakultas Teknik Universitas Hasanuddin, Makassar.

Syaeful, Heri dan Mellawati, June. 2013. Analisis alternatif tipe pondasi dan ekskavasi-dalam pada lokasi calon tapak pulau panjang, serang. Jurnal Pengembangan Energi Nuklir Volume 15, Nomor 2: (123-124).

Widjaja, Budijanto. 17 Juli 2004. Analisis Batas Untuk Kestabilan Lereng, (Online) (widjaja@home.unpar.acid, di akses unduh 5 Oktober 2017). 